\title{
Development of Business Competencies Based on Entrepreneurship in The Area of Urban Sprawl
}

\author{
${ }^{1} \mathrm{Ni}$ Nyoman Aryaningsih ${ }^{*},{ }^{2}$ Made.Marsa Arsana, ${ }^{3}$ Ketut Irianto \\ 1,2 Departement of Accounting, Bali State Polytehnic., Bali, Indonesia \\ ${ }^{3}$ Agriculture Faculty, Warmadewa University \\ ${ }^{3}$ Departement of Agriculture, Warmadewa University, Bali, Indonesia.
}

\begin{abstract}
Pressure of urban areas due to decreased function of the growth of productive land and settlement land, may lead the pressure problems and the movement of the number of urban residents to the suburbs. To maintain the public life of urban sprawl, efforts are needed to utilize and develop competence of people. This study aims to analyze the development of business competencies based on entrepreneurship in the area of urban sprawl. Business competence development is based on social competence, cognitive competence and self-competence. The Data was collected by distributing questionnaires, interviews and documentation. The validity and reliability of the data tested by factor analysis. The number of research samples was 100 respondents. Interview was done on 10 informants. Quantitative data analysis used Structural Equation Modeling Amos Version 16. The findings were: (1) Development of the competencies business is manning related to critical thinking, problem-solving, business adaptation to the business environment, and capable of interaction and communication in the market; (2) The entrepreneurial spirit of each individual in the urban sprawl associated to precautions includes thoroughness and prudence, not only of individual creativity; (3) Structural model of the relationship between the business competencies, entrepreneurship in the area of urban sprawl have a precision value of 0.96 (Goodness of Fit Index 96\%). Business activities is done by the society in urban sprawl, it is done to leisure and sustain their life. The benefits and the contribution of this study can provide information about the condition of the suburbs to all stakeholders and decision-makers, so it can be made by appropriate policy.

Keywords: development, business competence. entrepreneurship, urban sprawl
\end{abstract}

\section{INTRODUCTION}

The economic development of urban areas can create the problem of pressure and insistence of the population of the urban population and the impact compaction. the pressure caused by the urban areas of productive land decreased by about $30.92 \%$, growth in residential land amounted to $266.95 \%$. The Government reported the highest population density in Denpasar city classified as red zone conditions. As the administrative area of the city is very limited, so the city must utilize to the area suburbs. Brueckner ${ }^{1}$ proposed that the diversity of urban areas can be studied from the aspect of urban growth, infrastructure needs, as well as the need for land for the region grown up. Ideally comparison vast area woke up with urban areas is 40:60, while the Denpasar area as the city grown up by $70 \%$.

Increasing the area awakened as a result of increased population growth of $2.15 \%$ from the previous year is higher than the national average of $1.49 \%$, Cia ${ }^{2}$ Indonesia's
Email:1komangaryaningsih@ymail.com or arya68ningsih@gmail.com* Indonesia's population is $40 \%$ of the population in ASEAN countries and 55\% live in urban areas. Some of the impacts of the process of urban sprawl lead to changes in the pattern of economic activities towards non-agricultural population as traders, laborers, industry and services. Besides that the increasing number of urban population will cause various problems, namely: population growth, increased activity / economic activity and increases the extent of urban area size awakened. Aryaningsih, et al. ${ }^{3}$, It was found that social competencies, cognitive competencies and self competencies correlation to entrepreneurship in urban areas trading business. However, Brinkman in Cia ${ }^{3}$, suggested that the government's policy on urban areas will have an impact on the emergence of creative thinking around $17 \%$ in urban centers, so as to maintain the urban life decisions that have are doing business on the urbanrural transition area (urban sprawl).

Sudhira, et.al ${ }^{4}$ reported that the regional development 
of urban sprawl can influence on economic growth and improved economic opportunities. In addition, the World Bank report ${ }^{5}$ asserted that Indonesia needs to pay attention to "new business density", because Indonesia has a trade value of 0.29 entrepreneurship and lowest in Asia-Fasific. Problems faced by urban areas, causing overtopping the population of the city is (1) how to explore the economic potential of the total population, so as to contribute to the welfare of the community; (2) The shift / conversion of land use, especially the suburbs (the transition area townvillage): (3) the development of entrepreneurship and trade to improve the standard of living worthy $\mathrm{Sen}^{6}$; Wold Bank ${ }^{2}$. Harika $^{7}$ state that the region as a result of urban sprawl causing increased electrical energy requirements, and the value of the benefits of the use of electricity decreased $45.83 \%$. Schmiedinger ${ }^{8}$ showed that business management is very important and should utilize the the resources and the economic environment.

As reported by the World Bank study ${ }^{9}$, It shows that the city received a greater impact than the village due to overcrowding. Variations of the impact and implications of poor urban areas tend to decline in per capita income by $40 \%$,World Bank ${ }^{9}$. With the rapid population growth, causing increasing complexity of urban problems, so it appears the suburbs and the population of overtopping the city. The problem is not only limited to the provision of physical needs, but also a matter of economics as the source of life, social and cultural as working time utilization habits are changing. Sudhira, et.al ${ }^{4}$ found that urban sprawl is largely determined by the effective utilization of resources and reallocate infrastructure. Another research conducted Chan and Kam Wing ${ }^{10}$, showed that urban sprawl can lead to changes in social groups, income, number of unemployed. often considered problematic and utilization time is still less than optimal. Micell et al. ${ }^{11}$ found the global changes need competency-based training and a new concept of competency-oriented businesses More affluent residents flee the city centers and create constant

\section{METHODOLOGY}

The study was designed by explorative research models and quantitative-qualitatif approach. Data was collected by the methods surveys, and questionnaires. Characteristics of the study subjects invalve: (1) the standard of urban population densities are highest, an average of over 100 people/km2: (2) Denpasar city has a population density increased from $6,400 / \mathrm{km}^{2}$ to be $6,880 / \mathrm{km}^{2}$ in 2015 . Problems among rural area and urban are very different. It's implications were: (1) the efficiency of land use and the quality of people's living environment, especially the urban areas; (2) problems and the formulation of economic policy development. This research is directed to measure business

\section{RESULTS AND DISCUSSION}

\section{Validity and Reliability Tests with Factor Analysis}

From the validity and reliability test shows that variable business competencies have been a standard value of Kaiser-Meyer-Olkin (KMO) of 0.5 and It Total Variance Explainned (TVE) of $60 \%$. Validity Test of business competencies of $\mathrm{KMO}$ value of 0.835 is greater than 0.5 demand for new buildings, while the old ones fall into disrepair and thus fail to attract moderately-paid workers, creating a concentrated minority poor, Power ${ }^{12}$. This indicates the possibility to develop business competence and its use is optimal for creating the welfare of urban communities.

Modern century as the era of the return of every human being will be an important role of knowledge Azemikhah, ${ }^{13}$. Schmiedinger, et. $\mathrm{al}^{8}$ state that human competence is a combination of knowledge (explicit and implicit), skills and abilities are influenced by the needs, motives, personal goals, values, standards and attitudes. Implications of competence in the course of doing business based on the concept Siriwaiprapan ${ }^{14}$. Competency development into business competencies can be based on some derivation of the concept of competency. Quinn, et $\mathrm{al}^{15}$ stated that the competence and skills is related to knowledge/skill. Abraham \& Karns ${ }^{16}$ showed that the congruence between the competence of the business due to the clear identification as characteristic of successful entrepreneurs, business curriculum is also built in formal education. The results of other research, such as work as Lambert et $\mathrm{al}^{17}$ found that the main steps of the competency model development business through competency development process of empirical evidence, such as sales and marketing. The success of the individual, so that the development of more effective business competencies, then one can achieve the result of his work with certain qualifications and personal attributes. It is supported by the findings of Stefan ${ }^{18}$; Zammit, et al ${ }^{19}$ revealed that a business-oriented competence acquired through cognitive ability, mental, learning, experience, skill, and professionalism to form the happiness and independence. Erpenbeck and Rosenstiel ${ }^{20}$ also considered the need for measurement of competencies that focus on human competencies-based entrepreneurship.

competence based on entrepreneurship in areas of urban sprawl. The measurement of latent variables used: (1) business competence variable is constructed by social competence, cognitive competence and self competence; (2)Entrepreneurship variable is constructed by: imagination, creativity, innovation, awareness, discovery, self-leadership. (3) Urban sprawl was measured by land use, spending, government policies Community economic behavior Validity and Reliability of data questionnaire was tested by factor analysis. The validity of research data is greater than the value of KMO 0.5, while the reliability of the research data is greater than the value of Total Variance explainned $60 \%$. Data were analyzed by SEM-AMOS Version 16 .

standard and TVE value of $69.74 \%$ larger than the standard value TVE of $60 \%$. Variable business competencies with domains social competence, cognitive competence and self competence can be said to be valid and reliable. Entreprenurship value Tested is greater than the standard value. Entrepreneurship Tested has KMO value of 0.813 and TVE value of $63.54 \%$. Validity and reliability Tests showed that the value is above the standard. Urban sprawl 
was showed by land acquisition, land use, government policy. Validity and reliability tests was resulted in $\mathrm{KMO}$

\section{Testing of Structural Equation Model}

The test results show that models: estimation Confirmatory Factor Analysis (CFA) values obtained probability of 0.26. This figure means that there is no difference in constructs sample, because the observation probability value is greater than the probability of the standard value of 0.05 . The $P$ value of 0.26 indicates that there is no difference in samples

Table 1 shows that structural equation model or path analysis can accepted. It's means the higher the count of observations show that the indicators had constructed properly In addition, SEM as an analytical tool in the study has been appropriately used to test business competence development based on entrepreneurship in the area of urban sprawl. Referring to the results of the calculations have been done, then the Structural Equation Model can be depicted as in Figure 01.

Figure 1 shows the measurement of latent variable models and SEM test to results that have met the test of appropriateness and compatibility models. The calculation of Confirmatory Factor Analysis with empirical CR 0.26. is larger than the standard CR 0.05. Accordingly, the

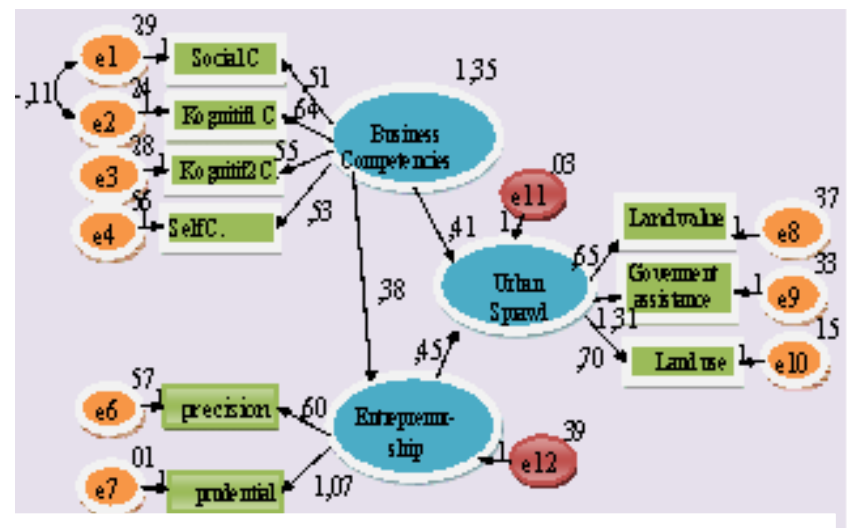

Figure-1. Testing of Structural Equation Model

competencies: critical thinking, problem solving, responsible for its business; (2) competence themselves as self adaptation, preparedness and act quickly. The SEM analysis shows that development of the business competencies development based on the social competence is interaction and communication; the cognitive competence is based on critical thinking and able to problems solving, while the self-competence based on individual adaptation. The results of personal interviews about the competence of the local businessman said that the urban sprawl of doing business should be value of 0.761 and TVE value of $69.48 \%$.

of the construct, so the test Confirmatory Factor Analysis with decent SEM can be continued. Conformance testing model (Model Fit SEM) can be proved by the test results is Goodness of Fit Index (GFI 0.96), Adjustment Goodness of Fit Index (AGFI 0.90), root mean square error of approximation (RMSEA by 0,04$)$, Tucker Lewis Index (TLI 0,99), and Comparative Fit Index (CFI of 0,99).

\begin{tabular}{llcl}
\multicolumn{4}{l}{ Table-1. Fit Evaluation } \\
\hline $\begin{array}{l}\text { DEFAULT } \\
\text { MODEL }\end{array}$ & $\begin{array}{l}\text { STANDARD } \\
\text { CRITERIA }\end{array}$ & $\begin{array}{l}\text { TESTING } \\
\text { RESULT }\end{array}$ & CRITERIA \\
\hline $\begin{array}{l}\text { The Critical Ratio } \\
\text { (Probability) }\end{array}$ & $\geq 0,05$ & 0.26 & Sig \\
CMIN/DF & $\leq 2,00$ & 1,19 & Sig \\
& & & $\cdot$ \\
GFI & $\geq 0,90$ & 0,96 & Fit \\
AGFI & $\geq 0,90$ & 0,90 & Fit \\
RMSEA & $\leq 0,08$ & 0,04 & Sig \\
TLI rho2 & $\geq 0,95$ & 0,99 & Fit \\
CFI & $\geq 0,95$ & 0,99 & Fit \\
\hline
\end{tabular}

Source: Primary Data is processed with SEM-AMOS version 16,Kaplan ${ }^{21}$

development of business competencies based entrepreneurship in the area of urban sprawl can provide accurate and significant. This research model can also be used as a quantitative approach to test the competence theory based business entrepreneurship.

friendly, patient and sincere to serve buyers. Furthermore, it is said that any activities that have been carried out must be done diligently and responsibly. It is caused by several factors of culture, habits and knowledge of individuals facing the challenges of changing times. Therefore, the calculation of some of the results of quantitative and qualitative development of business competencies necessary understanding of the complex. Complex understanding was based on the individual knowledge acquired through formal or non-formal, social and individual experience (interpersonal), internal and external motivation, responsiveness to environmental changes on the move, ready and quick to act, as well as the discipline of time. The research findings in accordance with Bontis et al. ${ }^{33}$; Marr \& Roos ${ }^{23}$; Subramaniam \& Youndt ${ }^{24}$; Anand et al. ${ }^{25}$ state that the ability to build new knowledge is very important and lead 
to changes very quickly from production-based economy to one based on knowledge. To this regard, Boons et.al ${ }^{26}$ state that while there is a considerable amount of knowledge on what drives sustainable innovation at the firm level, we know less about how sustainable innovation can be realized and win-win business situation can be created for those involved while actually enabling sustainability at the level of production and consumption systems.

\section{Entrepreneurship}

Entrepreneurial activity conducted by the business areas of urban sprawl is based on the awareness of individuals, namely: presicion and prudence in action. This is supported by the calculation of quantitative analysis of SEM. However, other indicators such as imagination, creativity, invention, and the leadership has not shown accurate results. The results showed that the indicator imagination interview with imagination and wishful thinking have not been well high. Creativity communities sprawl gray area is less visible than the power of creative thinking and the alternative chosen business. The discovery in a way to try and create still weak. Most areas of business activities carried out on the basis of urban sprawl because of the demands of life and besides follow what is done by others. Behavior like to follow other people's behavior can be regarded as an imitation of behavior, meaning that also not properly supervised by the relevant parties, the main purpose of land use is not clear. Government regulations about urban sprawl was not yet clear, so it requires more cluster region based on economic activities are made public. In addition, increasing the economic behavior of the business community should also be regulated by the government for land use does not violate zoning rules. and work commitments. People's behavior oriented to the prosperity of oneself and others through responsibility and the spirit of the work is expected to shape the character of positive thinking. The findings of Silambarasan, et al. ${ }^{34}$ showed that are increased in settlement and built-up land in urban sprawl is attributed to the intensive urbanization and industrial expansion in the recent time. A direct relation between increase in settlements and population expansion.

Competence of human resources in urban sprawl may increase revenue expectations to the existence of the business and value odds profit. This finding is consistent with the findings Ibrahimkhan ${ }^{31}$ that the qualification of human resources as a key strategy to reduce costs so that realized economic growth and maximizing profits. It is also reinforced by Powell \& Snellman ${ }^{32}$; Anand et al. ${ }^{25}$ that the

\section{LIMITATION}

This study still has limitations, because it is done in overtopping the city of Denpasar. These results are not capable of measuring the condition of the city overtopping quality and qualification of human resources in the region is increasing and growing.

\section{ACKNOWLEDGEMENTS}

Authors wish to Thank to Head of Bali State Polytechnic, Committee bisstech 2016 as an international conference mimics the behavior of others as deemed appropriate by himself. In addition, leadership in guiding and directing operations, and dominate the competition is still weak. This is caused by businesses in the area of urban sprawl activity due to economic pressures to maintain life. Besides, the leadership of the business is difficult to measure due to the efforts generally used as a source of household budgets for a living family. Klein ${ }^{27}$ was found that entrepreneurship as a function can be perfomed by a variety of indiviual under varying circumstances. According to Schnellenbach (2007) kinds of entreprenurship are as promoting political innovation . Finally, entrepreneurial activity is embedded in a particular institutional environment, Klein ${ }^{27}$; Williamson ${ }^{30}$. Any change in the institutional environment brought about by public-sector entrepreneurship changes the setting in which private-sector (and public sector) entrepreneurship takes place.

\section{Urban sprawl}

Business competencies in the areas of urban sprawl has performed diverse activities. It can be seen from the business location of the measured value of the land, local government support, the reference base government policy on land use. The basis of business development is not well understood, so that business activities overtopping city areas there are still weaknesses. The number of community organizations are

ability to build new knowledge is very important and lead to changes very quickly from production-based economy to one based on knowledge. As disclosed in the findings Bontis et al. ${ }^{33}$; Marr \& Roos ${ }^{23}$; Subramaniam \& Youndt ${ }^{24}$ that has the knowledge and competence will make it easier to access the network with other resources as well as how to use the knowledge so that it can produce a competitive advantage.

\section{CONCLUSION}

The findings of the study that the development of business competencies based on social competence, cognitive competence and self-competence. Competencies of business is based on every individual in the area of urban sprawl formed by vigilance include thoroughness and prudence and not just of individual creativity. Accuracy means appropriate estimates will change in environmental conditions, whereas as a precautionary measure risk aversion. The benefits and the contribution of this research may provide information to stakeholders about the condition of the people in the city overtopping proper use time and have been able to do different kinds of economic activities to improve their welfare.

organizers, and Institute of Research and Community Services who have given us the opportunity to present the results of research. Hopefully in this opportunity to grow

new ideas, so that the region's economic science and business management orientation of the growing sector.

\section{RECOMMENDATION}

Recommendation for future researchers should assess in depth the individual's competence in running a business in 
the city center and suburbs. Business growth depends on human nature and the individual's ability adapt,

\section{REFERENCES}

[1] Brueckner, Jan Keith, Largey, Ann G., (2006). Sosial Interaction and Urban Sprawl CESif.WP. No.1843. IER Unversity of Munich.

[2]Chia, Siow Yue (2013). The ASEAN Economic Community: Progress, Challenges, and Prospects. No. 440 October 2013, ADBI Working Paper Series, No. 440. October 2013 ,

[3]Aryaningsih,NN, Md Marsa Arsana and LM.Wahyuni (2015). Effects of Competencies, Entrepreneurship Spirit, to Competitiveness, and Income Expectation to Increasing Cummunity Welfare of The Weak Economic in Denpasar City. Senapati Proceeding National. PNB.

[4] Sudhira, H.S, T.V. Ramachandra K.S.Jagadish (2003). Urban sprawl: metrics, dynamics and modelling using GIS,Journal of Applied Earth Observation and Geoinformation 5 (2004) 29-39.

[5] Wold Bank (2013) Word Bank Report Jakarta; Indonesia.

[6] Sen, A. (2002), Agen of Change. Discussion document from an interview at Cambridge filmed by TVE.

[7] Harika M. (2013) "Landuse/landcover changes detection and urban sprawl analysis", International Journal of Advanced Scientific Research and Technology, vol.2, April 2013, pp: 383-396.

[8] Schmiedinger, Bernhard; Klaus Valentin, Elisabeth Stephan, (2005), Competence Based Business Development-Organizational Competencies as Basis for Successful Companies. Proceedings of IKNOW'05 Graz, Austria, June 29 - July $1 .$.

[9] Word Bank (2006) Report Jakarta; Indonesia.

[10] Chan and Kam Wing (2012) "Crossing the 50 Percent Population Rubicon: Can China Urbanize to Prosperity?", Eurasian Geography and Economics, vo1.53 issue 1, 2012, pp: 63-86.

[11] Micell T.J., and Sirmss, CF., (2004), The Houldout Problem and Urban Sprawl, Economic Working Papers, Departement of Economic, University of Conneccticut.

[12] Power, A., 2001. "Social Exclusion and Urban Sprawl: Is the Rescue of Cities Possible?" Regional Studies, Vol. 35, No. 8, p. 731-742.

[13] Azemikhah, H. (2005). The design of competency based learning resources for VET training packages using learner centred, work centred and attribute focused simulation strategies. Paper presented at the Australian Vocational Education and Training Research Association Conference, 8th, Brisbane, 2005, Brisbane.

[14] Siriwaiprapan, S. (2000). The concept, practice, and future of human resources development as perceived by Thai human resources practitioners. Unpublished responsiveness, and readiness to act.

doctoral dissertation, George Washington University, Washington DC.

[15] Quinn, E. R., Faerman, R. S., Thompson, P. M., \& McGrath, R. M. (1990). Becoming a master manager: A competency framework, New York: John Wiley \& Sons.

[16] Abraham,S., and Karns, L., (2009), Do Business school value the Competencies that business value? Journal of Education for Business Vol.84.Iss.6.pp.350356.

[17] Lambert,B., Plank,R.E., Reid,D.A. and Fleming, D. (2013). A Competency Model For Entry level Business to Business Services Sales People. J Services Marketing Quarttely Vo.35.Issue 1.2014

[18] Stefan Eicker, J.Kochbeck, and P.M. Schhuler, (2008), Emplyee Competencies for Business Process Management. W.Abramowicz and D,Fensel (Eds): BIS.2008,LNBIP.pp.251-262 (2008) @springer Verlag Berlin Heldelberg.

[19] Zammit, S., Kounali D. Cnnon M.,et al (2013) Prevalence and prediction of psychotic experience, prodromal syndromes and psychometic disorder at age $18 \mathrm{i}$ a longitudinal population-based cohort study. Am J.Psychiatry (in press).

[20] Erpenbeck, John and Lutz von Rosenstiel, Lutz (Hrsg.) (2003).Handbuch Kompetenzmessung. Erkennen, verstehen und bewerten von Kompetenzen in der betrieblichen, pädagogischen und psychologischen Praxis. Schäffer-Poeschel

[21] Kaplan, D., (2000), Structural Equation Modeling, Thousand Oaks,Sage

[22] Bontis, N., Ashour,A., Seleim,A., (2004),Intellectual Capital in Egyptian Software Firms, The Learning Organiation, Vol.11.Iss45.pp.332-346.

[23] Marr, B. and Roos, G. (2005). A strategy perspective on intellectual capital in Perspectiveson Intellectual Capial-Multidisciplinary Insights into Management;Measurement and Reporting (Marr,B. ed.). Oxford: Butterworth- Heinemann.

[24] Subramaniam, M. and Youndt, M. A. (2005), "The influence of intellectual capital on the types of innovative capabilities", Academy of Management Journal, Vol.48 No. 3, pp. 450-463.

[25] Anand, N., Gardner, H. K. and Morris, T. (2007), "Knowledge-based innovation: Emergence and embedding new practice areas in management consulting firms", Academy of Management Journal, Vol. 50 No. 2, pp. 406-426.

[26] Boons, F., Montalvo,C., Quit,J., Wagner,M., (2013). Sustainable Innovation, business models and economic perfomnce: An overview. Journal Clean. Prod,45,1-8.

[27] Klein, P. G., 2008, "Opportunity discovery, entrepreneurial action, and economic organization". Strategic Entrepreneurship Journal, 2: 175-190.

[28] Schnellenbach, J., 2007, "Public entrepreneurship and the economics of reform". Journal of Institutional Economics, 3: pp.183-202.

[29] Klein, P. G., 2000, "New institutional economics"'. In B. Bouckeart and G. De Geest (eds.) Encyclopedia of law and economics Cheltenham, UK: Edward Elgar, 
pp. 456-489.

[30]Williamson, O. E., 2000, "The new institutional economics: Taking stock, looking ahead". Journal of Economic Literature, 38: pp.595-613.

[31] Ibrahimkhan, M.W., (2006), Income as a possible factor factor in the employment of Saudis in Private and Public Sector Organiation, George Washington University, Washington DC. Linked. Vaishya,R., Sumi Jha, D.K.Srivastava (2016), Revisiting Managerial Competencies, Literature Review, Vol.5.Iss.4.March.

[32] Powell,W.W., and Snellman,K., (2004), The Knowledge

Economy,

Annu.Rev.Social..2004.30.pp.199-

230.doi:10.1146annurev.29010202/100037.

[33] Bontis, N., Keow, W. C. C. and Richardson, S. (2000), "Intellectual capital and business performance in Malaysian industries", Journal of Intellectual Capital, Vol. 1 No. 1, pp. 85-100. 
